\title{
Is Microscopic Colitis a Drug-induced Disease?
}

Citation for published version (APA):

Keszthelyi, D., Penders, J., Masclee, A. A., \& Pierik, M. (2012). Is Microscopic Colitis a Drug-induced Disease? Journal of Clinical Gastroenterology, 46(10), 811-822. https://doi.org/10.1097/MCG.0b013e3182618506

Document status and date:

Published: 01/01/2012

DOI:

10.1097/MCG.0b013e3182618506

Document Version:

Publisher's PDF, also known as Version of record

Document license:

Taverne

Please check the document version of this publication:

- A submitted manuscript is the version of the article upon submission and before peer-review. There can be important differences between the submitted version and the official published version of record.

People interested in the research are advised to contact the author for the final version of the publication, or visit the DOI to the publisher's website.

- The final author version and the galley proof are versions of the publication after peer review.

- The final published version features the final layout of the paper including the volume, issue and page numbers.

Link to publication

\footnotetext{
General rights Owners
rights.

- You may freely distribute the URL identifying the publication in the public portal. please follow below link for the End User Agreement:

www.umlib.nl/taverne-license

Take down policy

If you believe that this document breaches copyright please contact us at:

repository@maastrichtuniversity.nl

providing details and we will investigate your claim.
}

Copyright and moral rights for the publications made accessible in the public portal are retained by the authors and/or other copyright owners and it is a condition of accessing publications that users recognise and abide by the legal requirements associated with these

- Users may download and print one copy of any publication from the public portal for the purpose of private study or research.

- You may not further distribute the material or use it for any profit-making activity or commercial gain

If the publication is distributed under the terms of Article $25 \mathrm{fa}$ of the Dutch Copyright Act, indicated by the "Taverne" license above, 


\title{
Is Microscopic Colitis a Drug-induced Disease?
}

\author{
Daniel Keszthelyi, MD, ${ }^{*}$ John Penders, PhD, $\dagger+$ Ad A. Masclee, MD, PhD,* \\ and Marieke Pierik, MD, PhD*
}

\begin{abstract}
Microscopic colitis (MC) is diagnosed in up to $13 \%$ of patients investigated for chronic diarrhea, particularly in middleaged and elderly patients. Recent studies have suggested an etiological role for various drugs, including nonsteroidal antiinflammatory drugs and proton pump inhibitors. To ascertain the potential role for drug exposure in the development of MC, we performed a systematic review based on a MEDLINE search and conducted a meta-analyses on the available data. We also give an overview of the case reports and studies illustrating the role of drugs in inducing MC. A number of hypotheses are formulated with regard to the potential pathophysiological mechanisms in drug-induced MC. However, confirmative evidence is still largely lacking. Considering the high number of drug users and the relatively low incidence of $\mathrm{MC}$, it is more likely that drug-induced cases of MC are the result of an idiosyncratic reaction.
\end{abstract}

Key Words: microscopic colitis, drug exposure, proton pump inhibitors, NSAIDs, systematic review, collagenous colitis, lymphocytic colitis

( Clin Gastroenterol 2012;46:811-822)

$\mathrm{M}$ icroscopic colitis (MC) is an umbrella term for collagenous colitis (CC) and lymphocytic colitis (LC). MC is characterized by the combined presence of watery diarrhea, a macroscopically normal ileocolonoscopy and typical microscopic findings. ${ }^{1}$ The histologic changes of MC comprise an increased number of intraepithelial $\mathrm{CD} 8{ }^{+} \mathrm{T}$ lymphocytes, exceeding 20 per 100 surface epithelial cells, accompanied by superficial epithelial damage and a variable inflammatory infiltrate in the lamina propria. In addition, in CC, a thickened subepithelial collagen band, which exceeds $10 \mu \mathrm{m}$, is present. These histologic characteristics are not pathognomic as they may occur in various inflammatory conditions in the colon. ${ }^{2}$

$\mathrm{MC}$ can be diagnosed in patients of any age, but primarily affects the elderly. The average age of patients diagnosed with LC or CC ranges from 53 to 69 years. ${ }^{3}$ Also, MC seems to be more frequent in women than in men. In the past, $\mathrm{MC}$ was thought to be a rare disorder. However, it has recently become apparent that $\mathrm{MC}$ is diagnosed in up to $13 \%$ of patients investigated for chronic diarrhea, particularly if middle-aged or elderly. ${ }^{2,4}$ Pardi et $\mathrm{al}^{4}$ reported an increasing annual incidence rate up to 7.1 for CC and up to 12.6 for LC per 100,000 person-years in the period of 1998 to 2001. Along the same line,

From the Departments of *Internal Medicine, Division of Gastroenterology-Hepatology; †Epidemiology; and \$Medical Microbiology, Maastricht University Medical Center, Maastricht, The Netherlands.

The authors declare that they have nothing to disclose.

Reprints: Daniel Keszthelyi, MD, Division of Gastroenterology-Hepatology, Department of Internal Medicine, Maastricht University Medical Centre, PO Box 5800, 6202 AZ Maastricht, The Netherlands (e-mail: daniel.keszthelyi@maastrichtuniversity.nl).

Copyright (C) 2012 by Lippincott Williams \& Wilkins
Scandinavian studies have also shown increasing incidences for both LC and CC (Table 1).

It is apparent that the induction of inflammation in the lamina propria is a key pathogenetic factor in MC. However, the exact mechanisms involved in the initiation and development of $\mathrm{MC}$ remain to be elucidated and several pathophysiological mechanisms have been proposed. Genetic susceptibility was suggested because of reports of familial clustering of the disease. ${ }^{10,11}$ Secondly, the reported seasonal variation in incidence indicates an infectious cause. ${ }^{12}$ To date, no causal enteropathogen has been identified and antibiotics are not effective in the treatment of MC. Over $40 \%$ of the patients with $\mathrm{MC}$ have coexisting autoimmune diseases such as celiac disease or thyroiditis pointing to potential involvement of autoimmune mechanisms., 2,6,13 Furthermore, for CC, myofibroblast dysfunction has been described. ${ }^{14-16}$ Finally, noxious luminal substances such as drugs and smoking may trigger the chronic inflammation seen in $\mathrm{MC}$ and one postulated hypothesis points to increased colonic permeability in $\mathrm{MC}$ patients, thereby allowing luminal antigens to enter the lamina propria and elicit an immune and inflammatory reaction. ${ }^{17}$

The increasing incidence of MC may partially be explained by an increased awareness of the condition among clinicians and histopathologists. Moreover, a variety of drugs has been associated with MC and has even been suggested to induce MC. The increased use of medications especially in older people might explain the reported increased incidence of $\mathrm{MC}{ }^{3}$ To shed more light with regard to current evidence regarding the role of drug exposure in $\mathrm{MC}$ and the mechanisms involved we performed a systematic review of the literature.

\section{MATERIALS AND METHODS}

\section{Literature Search}

We executed a MEDLINE search using the terms: "microscopic colitis" or "lymphocytic colitis" or "collagenous colitis." The language restrictions were English, French,

TABLE 1. Incidence Rates (per 100,0000) of Collagenous Colitis (CC) and Lymphocytic Colitis (LC)

\begin{tabular}{|c|c|c|c|c|}
\hline & $\begin{array}{c}\text { Period } \\
\text { Investigated }\end{array}$ & $\mathbf{C C}$ & $\mathbf{L C}$ & References \\
\hline \multirow[t]{2}{*}{ USA } & $1985-1997$ & 1.6 & 2.7 & Pardi et $\mathrm{al}^{4}$ \\
\hline & $1998-2001$ & 7.1 & 12.6 & \\
\hline \multirow[t]{2}{*}{ Sweden } & 1984-1993 & 1.8 & $\begin{array}{l}\text { No } \\
\text { data }\end{array}$ & Bohr et $\mathrm{al}^{5}$ \\
\hline & 1993-1998 & 4.9 & 4.4 & Olesen et $\mathrm{al}^{6}$ \\
\hline Iceland & $1995-1998$ & 5.2 & 4.0 & Agnarsdottir et $\mathrm{al}^{7}$ \\
\hline Spain & 1993-1997 & 2.3 & 3.7 & $\begin{array}{l}\text { Fernandez-Banares } \\
\text { et } \mathrm{al}^{8}\end{array}$ \\
\hline Canada & $2002-2004$ & 4.6 & 5.4 & Williams et $\mathrm{al}^{9}$ \\
\hline
\end{tabular}




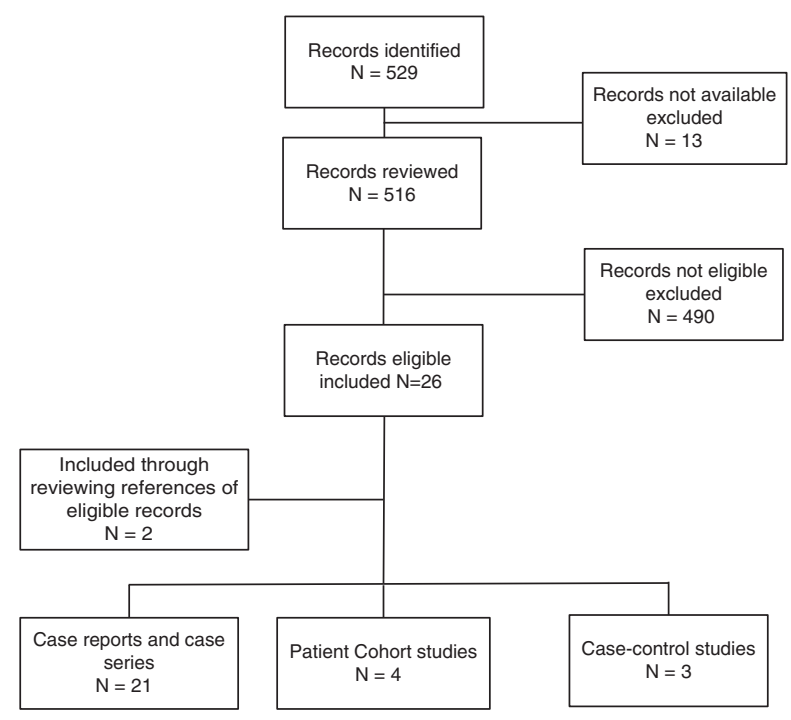

FIGURE 1. PRISMA flowchart for literature search.

German, or Dutch. The initial search resulted in 529 hits. The abstract, or when available, the full paper was reviewed by 2 reviewers independently and papers were excluded if not reporting on drugs and MC. For 13 hits, no abstract or paper was available and were therefore excluded. After initial review, 26 papers were found eligible for further review. Review of the references of the included papers resulted in 2 additional case reports (see Fig. 1 for PRISMA flowchart).

\section{Meta-analysis}

Eventually, the meta-analysis was performed using data from the only 3 case-control studies assessing exposure to medication in MC. ${ }^{18-20}$ These 3 studies all reported on nonsteroidal anti-inflammatory drugs (NSAIDs) and only 2 of them on proton pump inhibitors (PPIs). Therefore, only data on NSAID exposure were considered for meta-analysis. Also, the patient populations examined were not entirely homogenous, some examining CC and LC separately, for instance. For this reason, in case of the study of Fernandez-Banares et al, ${ }^{19}$ we pooled the drug exposure rates from $\mathrm{CC}$ and $\mathrm{LC}$ cases before the meta-analysis.

For each of the included studies, odds ratios (ORs) and their $95 \%$ confidence intervals were calculated based upon the reported drug exposure rates in MC patients and controls. To derive a pooled OR from individual studies, we used a random-effects meta-analysis model. It is important to note, that we were not able to correct ORs for age, sex, and other confounders and therefore only report crude ORs. Heterogeneity was quantified with the $I^{2}$ index, which describes the proportion of total variation in study estimates due to heterogeneity. ${ }^{21}$

Statistical analyses were conducted using the "metan" command within Stata version 11 (Stata Corp., College Station, TX). The results are displayed in a forest plot.

\section{RESULTS AND DISCUSSION}

\section{NSAIDs}

Of all drug groups suggested to play an etiological role in $\mathrm{MC}$, the most convincing evidence exists for NSAIDs. A summary of case reports of NSAID-induced MC is given in Table 2. We also present a summary of cases reporting on the association with the exposure to Cyclo 3 forte, a venotonic drug used in France, also containing aspirin (Table 3). It is, however, important to acknowledge that it is unclear whether the association is related to aspirin or the other components on Cyclo 3 forte.

In an early prospective study, NSAIDs were implicated in $10 \%$ of newly diagnosed cases of colonic inflammation, and patients taking NSAIDs had a 5-fold risk for developing a colonic disease. ${ }^{29}$ In later years, a substantial number of studies have reported on a positive association with NSAID exposure and $\mathrm{MC}^{20,23,30-32}$ (see Table 4 for cohort studies). This association seems more apparent with CC. ${ }^{19}$ Numerous studies have reported high use of NSAIDs among MC patients. In a retrospective review of 163 patients in Sweden with CC, 34\% were taking NSAIDs on a regular or sporadic basis. ${ }^{35}$ Another Scandinavian study showed that $35 \%$ of the 104 patients with MC examined used NSAIDs. ${ }^{36}$ In a case control study by Riddell, 31 patients with $\mathrm{CC}$ were compared with 31 controls with irritable bowel syndrome or diverticulosis. Long-term use of NSAIDs (for $>6 \mathrm{mo}$ ) was reported in 19 of 31 subjects with MC, compared with only 4 of 31 controls. The case for an etiological role for NSAID use and MC was strengthened by reports of clinical and histologic improvement among NSAID users when the medication was discontinued..$^{20,23-25}$ In the controlled study of 31 patients with CC described previously, 3 subjects reported reduction in diarrhea after they stopped taking NSAIDs. One subject, who later resumed taking an NSAID, developed recurrent diarrhea that resolved when the NSAID was again discontinued. ${ }^{20}$

Given this apparent role for NSAIDs in MC, we performed a meta-analyses based on the 3 case-control studies published to date [pooled OR 3.25 (1.1-9.5), see Fig. 2 for forest plot]. Although we did calculate the pooled OR for NSAID exposure, it is important to note that this should be interpreted with caution for the following reasons. First, the number of published studies available for analysis is limited. Second, no correction was possible for other confounders, since Riddell et $\mathrm{al}^{20}$ did not present adjusted analyses, whereas we had to pool the drug exposure rates of LC and CC for the study by FernandezBanares et $\mathrm{al}^{19}$ before meta-analyses. Third, the studies report on different patients populations (MC pooled together or LC and CC separately) as well as control population (general population, patients controls or a mixture of both). We therefore consider the findings of these meta-analyses indicative rather than conclusive regarding a possible etiological role for NSAIDs.

A potential confounding factor is the presence of coexisting arthralgia in patients with $\mathrm{MC}$, which could increase their use of NSAIDs. ${ }^{37}$ A study reported that 18 of $31(56 \%)$ patients with CC had some form of arthritis; and $71 \%$ of those were using NSAIDs regularly at the time of diagnosis. ${ }^{9}$ Establishment of a cause-effect relationship here is exceptionally challenging and cannot be performed on the basis of the currently available datasets. Nevertheless, several hypotheses can be postulated with regard to potential pathophysiological mechanisms. Intestinal side effects of NSAID have been documented extensively. NSAIDs induce small intestinal and colonic injury and inflammation and possibly may exacerbate IBD. ${ }^{32}$ Furthermore, $60 \%$ to $70 \%$ of patients on long-term NSAID may have asymptomatic enteropathy. ${ }^{32}$ NSAID intake has 




\begin{tabular}{|c|c|c|c|c|}
\hline & \multicolumn{4}{|c|}{ Study } \\
\hline & Sveinsson et al $^{33}$ & Pardi et al $^{34}$ & Goff et al $^{31}$ & Bohr et al $^{35}$ \\
\hline Study design & $\begin{array}{l}\text { Nation-wide cohort new } \\
\text { diagnosed MC } \\
\text { patients }\end{array}$ & $\begin{array}{l}\text { Single-center } \\
\text { Mayo Clinic }\end{array}$ & $\begin{array}{l}\text { Single-center University } \\
\text { Michigan }\end{array}$ & $\begin{array}{l}\text { Registry } 25 \text { Swedish } \\
\text { hospitals }\end{array}$ \\
\hline Inclusion period & 1995-1999 & 1997-1999 & Before 1992 & 1989-1995 \\
\hline $\mathrm{MC}$ & 125 & 189 & 31 & 163 \\
\hline $\mathrm{LC}$ & 71 & 176 & - & - \\
\hline $\mathrm{CC}$ & 54 & 6 & 31 & 163 \\
\hline Method & Patient questionnaire & $\begin{array}{l}\text { Retrospective } \\
\text { chart review }\end{array}$ & $\begin{array}{l}\text { Retrospective chart } \\
\text { review and telephone } \\
\text { interview }\end{array}$ & $\begin{array}{l}\text { Retrospective chart } \\
\text { review }\end{array}$ \\
\hline \multicolumn{5}{|l|}{ NSAIDs at diagnosis } \\
\hline $\mathrm{MC}$ & $33 \%$ & $\begin{array}{l}\text { Aspirin } 43.9 \% \\
\text { Other NSAIDs } 24.3 \% \\
\text { Ticlopidine } 3.7 \% *\end{array}$ & - & - \\
\hline $\mathrm{LC}$ & $17 \%$ & - & - & - \\
\hline $\mathrm{CC}$ & $41 \%$ & - & $71 \%$ & $33.6 \%$ \\
\hline $\begin{array}{l}\text { Other medication at } \\
\text { diagnosis }\end{array}$ & & $\begin{array}{l}\text { Lansoprazole } 3 \\
\text { Bupropion } 2 \\
\text { Sertraline } 2 \\
\text { Colchicine } 2 \\
\text { Etanercept } 1 \\
\text { Carvedilol 1 } \\
\text { Metformin } 1 \\
\text { Omeprazole } 1 \\
\text { Valproci acid } 1 \\
\text { Amitryptyline } 1 \\
\text { Troglitazone } 1 \\
\text { Niacin 1 } \\
\text { Hydrochloroquine } 1 \\
\text { Cisapride 1 }\end{array}$ & & \\
\hline
\end{tabular}

*For 2 patients on ticlopidine dechallenge resulted in cessation of diarrhea.

CC indicates collagenous colitis; LC, lymphocytic colitis.

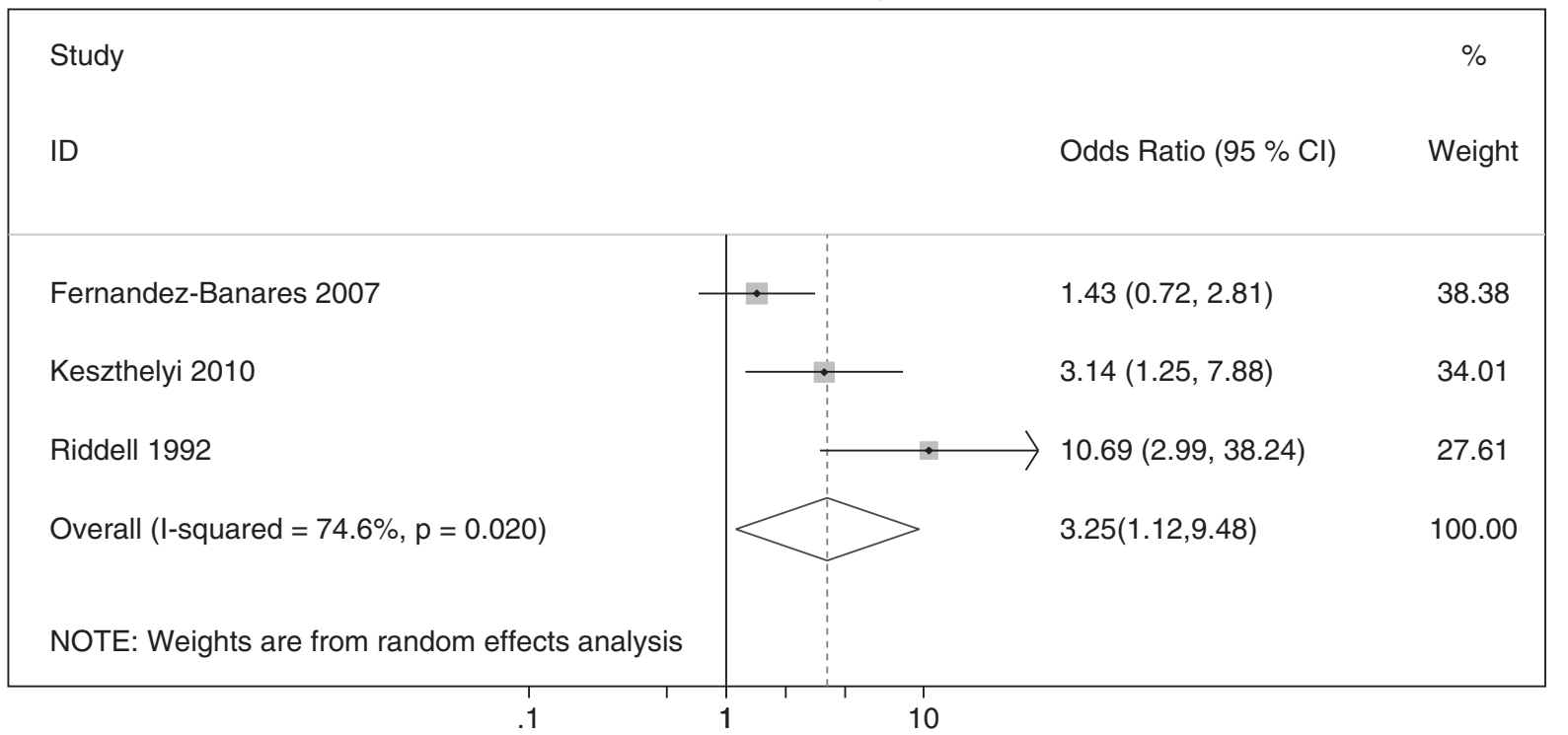

FIGURE 2. Forest plots for meta-analysis of nonsteroidal anti-inflammatory drug (NSAID) use in microscopic colitis. Cl indicates confidence interval. 
in fact been associated with increased risk for acute diarrhea. ${ }^{38}$ More recently, Gleeson and Davis ${ }^{39}$ reported that $74 \%$ of new cases presenting with colitis had been using NSAIDs before the development of their disease.

Therefore, the alleged ability of NSAIDs to cause or at least exacerbate MC is not altogether unexpected. NSAIDrelated erosions and ulcers are most commonly seen in the distal ileum and rectum. Small intestinal injury due to NSAIDs differs pathophysiologically from that found in the stomach, as prostaglandin suppression does not play an important role. ${ }^{40}$ Rather, NSAIDs and bile have synergistic effects with respect to injury of the small intestine by contact irritation of the mucosa. The enterohepatic circulation seems to be crucial in this regard, by allowing repeated exposure to the offending chemicals. In the small intestine, NSAIDs uncouple mitochondrial oxidative phosphorylation leading to reduced intracellular ATP levels. This, in turn, leads to loss of cytoskeletal control over tight junctions and increased paracellular permeability. ${ }^{41}$ This increased permeability may allow passage of certain, yet to be identified luminal antigens, which can elicit a malicious immune response, which, provided such mechanism is also present in the colon, may potentially result in clinically manifest MC.

\section{PPIs}

Recent studies have emphasized the association between exposure to PPIs and occurrence of MC. Many case reports have been published that further highlight the association between PPI use and development of $\mathrm{MC}^{42-45}$ (Table 5). Initially, lansoprazole has been associated with a high likelihood of inducing MC ${ }^{50}$ In most published cases, symptoms started within few weeks after start of lansoprazole therapy (median $21.5 \mathrm{~d}$ ), and complete resolution after lansoprazole discontinuation was observed within a few days (median $7 \mathrm{~d}$ ), without need for further therapy. ${ }^{51}$ Another recent study also pointed to similar effects in case of exposure to omeprazole and esomeprazole. ${ }^{45}$ PPIs are one of the most frequently prescribed classes of medications worldwide because they combine a high level of efficacy with low toxicity. In 2006, expenditure on these drugs was 10 billion USD globally. ${ }^{52}$ In the 5 years since the introduction of esomeprazole in 2001, prescriptions for PPIs have doubled. ${ }^{52}$ It is noteworthy, that the increasing incidence of $\mathrm{MC}^{4}$ seems to parallel the rising use of PPIs.

Besides a number of case reports and case series, only a very limited number of controlled studies have examined the role of PPI exposure in MC, ${ }^{18,19}$ of which only one found a positive association. ${ }^{18}$ More comprehensive studies are still lacking for PPIs to support an etiological role for PPIs in MC.

The potential pathophysiological mechanisms underlying PPI-related induction of MC are poorly understood. When patients are prescribed PPIs to treat upper gastrointestinal disorders, it is important to recognize that PPIs are interacting at multiple targets. Proton pumps $\left(\mathrm{H}^{+} / \mathrm{K}^{+}\right.$ ATPases) are present not only on gastric epithelium but also on colonic epithelium where they contribute to wholebody potassium homeostasis. ${ }^{53}$ Inhibition of the colonic proton pumps may therefore affect local electrolyte balance and compromise fluid acidification, which can possibly affect immune reactions in the colonic mucosa. Autoradiographic studies using ${ }^{3} \mathrm{H}$-lansoprazole in animal models have shown uptake of the drug in the colonic mucosa, both in upper colonic epithelial cells as well as in inflammatory cells. ${ }^{54}$

Proteins other than $\mathrm{H}^{+} / \mathrm{K}^{+}$ATPase have also been reported as targets for PPIs. Omeprazole and lansoprazole have been observed to induce smooth muscle relaxation and to inhibit contractile activity. ${ }^{53}$ This effect on contractile systems may also affect tight junction functionality as tight junction proteins are directly linked to the actinomyosin cytoskeleton. Therefore, conformational changes in the cytoskeleton of epithelial cells may result in alterations in the function of the tight junction, which leads to increased paracellular permeability. As a result, luminal contents can more easily penetrate the lamina propria causing an immune and/or inflammatory reaction. Esomeprazole has been shown to increase paracellular permeability in the upper gastrointestinal tract in vitro ${ }^{55}$ and in vivo in humans. ${ }^{56}$ Increased paracellular permeability has been observed in MC and is considered a key component in the induction of diarrhea. ${ }^{57}$ Accordingly, expression of the tight junction proteins occludin, claudin-4, and zonula occludens-1 was found to be decreased in mucosal biopsy specimens from MC patients. ${ }^{57,58}$ We speculate that a direct or indirect effect of PPIs on colonic tight junctions and paracellular permeability, similar to that of NSAIDs, may be a potential mechanism in the development of MC.

Recent case reports have related the occurrence of severe hypomagnesemia to long-time PPI exposure. ${ }^{59,60}$ This effect has been described for omeprazole, esomeprazole, pantoprazole, and lansoprazole. ${ }^{59}$ It has been proposed that PPIs induce a defect in the active absorption of magnesium in the intestine. This may result from an effect of PPIs on the tight junction proteins or on the TRPM6 and 7 channels (transient receptor potential melastin 6 and 7). The latter are key molecules involved in active magnesium absorption. Either changes in intestinal $\mathrm{pH}$ induced by PPIs may affect channel functions, or subjects who are heterozygous carriers of TRPM6/7 mutations are more susceptible to developing adverse reactions to PPIs. ${ }^{60}$ Presently, we cannot exclude that effects of PPIs on magnesium absorption have a role in the pathogenesis of MC. The fact that distinct genetic profiles can be of superior importance with regard to the development of side effects during PPI therapy is further supported by reports describing agranulocytosis and neutropenia induced by PPI. ${ }^{61} \mathrm{~A}$ recent report demonstrated that this is caused by a mutation of the CYP2C19*17, the enzyme responsible for PPI metabolism. ${ }^{62}$

In addition, it is well known that PPI therapy affects intestinal microbial profiles. ${ }^{63-66}$ Several bacteria, including Helicobacter pylori and Streptococcus pneumoniae, as well as fungi such as Candida albicans, contain $\mathrm{H}^{+} / \mathrm{K}^{+}$ ATPase in their plasma membranes that are highly homologous to their human counterparts. ${ }^{67}$ PPIs can therefore directly influence microbial growth by inhibition of the $\mathrm{H}^{+} / \mathrm{K}^{+}$ATPase. In contrast, increase of intestinal $\mathrm{pH}$ can result in a diminished host defense against certain bacteria. Profound acid suppression increases the risk of enteric infections in susceptible individuals caused by Shigella, Salmonella, Yersinia, or Clostridium difficile. ${ }^{68}$ The use of PPIs may also promote the expansion and colonization of $C$. difficile by its recognized potential to induce small bowel bacterial overgrowth with anaerobic colonic organisms. ${ }^{63}$ Many clinicians believe that PPI use may therefore directly contribute to $C$. difficile and other bacterial infections. The FDA has in fact recently issued a 


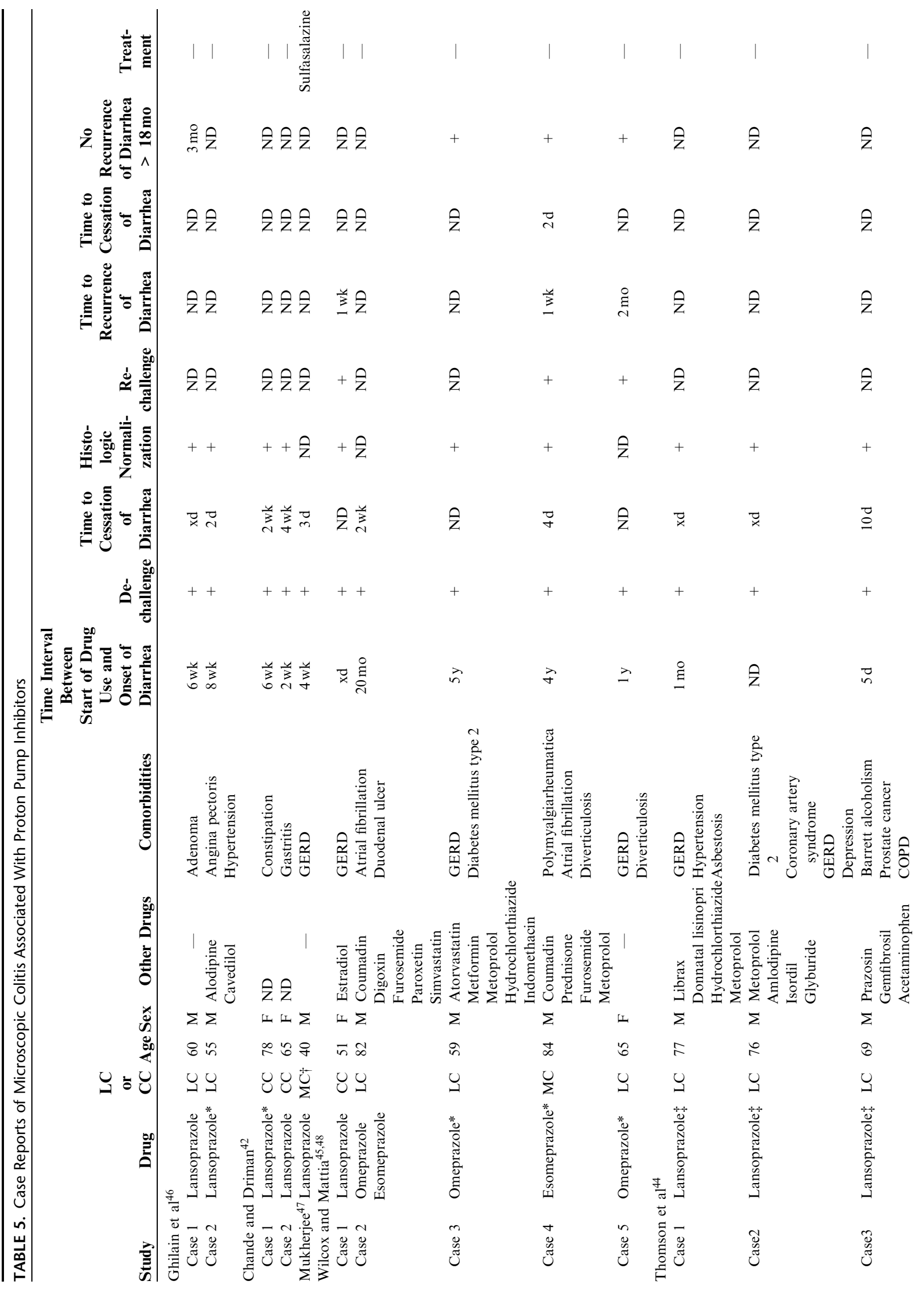




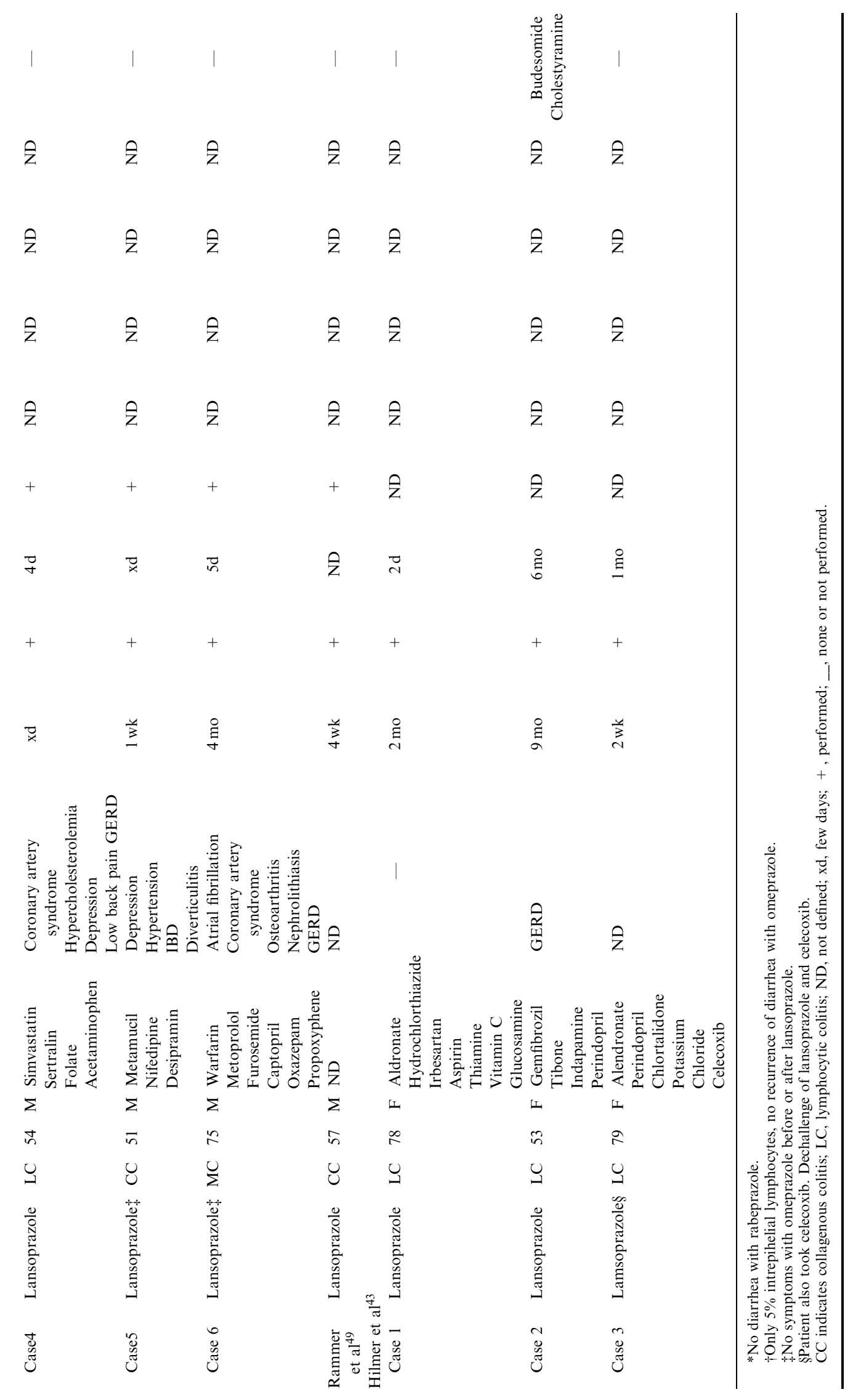


safety announcement that PPI use may be associated with C. difficile infection. ${ }^{69}$ A recent study by Lombardo et $\mathrm{al}^{70}$ also suggested that PPI therapy in humans may potentially result in small intestinal bacterial overgrowth. Whether these changes in intestinal microbiota induced by PPI therapy are truly responsible for the development of symptoms and clinical conditions remains subject to considerable discussion. ${ }^{71}$ Further research is needed to clarify the exact effects of PPIs on human intestinal microbiota.

Nevertheless, alterations in intestinal microbiota should also be considered as a possible pathogenetic factor in MC. The role of microbiota in regulating intestinal function has increasingly been appreciated and perturbation of intestinal microbiota seems plausible in MC. ${ }^{72}$ The anatomic sites of highest bacterial concentration in the gut (cecal and right colon) are the sites most frequently affected by inflammation. ${ }^{30}$ There is also some, albeit not robust, evidence that $\mathrm{CC}$ patients may benefit from treatment with probiotics. ${ }^{73}$

\section{Coexposure to NSAIDs and PPIs}

PPIs and NSAIDs are often used simultaneously, with the former frequently coprescribed to reduce gastrointestinal injury due to the latter. Recent video capsule studies suggest ${ }^{74,75}$ a very high incidence ( $55 \%$ to $70 \%$ ) of intestinal damage in healthy humans taking both NSAIDs and PPIs for 2 weeks. A more recent study performed in rats demonstrates that PPIs induced a marked exacerbation of small intestinal ulceration induced by NSAIDs, which was transferable to germ-free mice through microbiota isolated from the PPI-treated rats, suggesting an important role for microbial alterations. When PPIs were administered alone, significant changes in intestinal microbiota were observed, with $80 \%$ reduction in the levels of the beneficial Bifidobacteria spp., whereas little morphological effect was detected on the intestinal mucosa. ${ }^{76}$

Overall, it is tempting to assume that PPIs can potentially induce alterations in intestinal microbiota, albeit not to a clinically significant degree, which can in turn impair the capacity of the intestine to respond to potentially noxious agents, such as NSAIDs, known also to affect intestinal barrier function. Such a "2-hit" theory could provide an explanation for the relevance of coexposure to PPIs and NSAIDs in the development of MC. Recent results suggest a higher intake of PPIs with NSAIDs in patients with MC compared with controls from the general population. ${ }^{18}$ However, in the published case reports, only 2 of 20 patients were using PPIs and NSAIDs simultaneously. Further studies are warranted to provide confirmative evidence on this potential additive effect of coingestion.

\section{Other Drugs}

A number of other drugs have been proposed to be associated with MC (Table 6). Ticlopidine, for instance, has also been reported in a number of cases to be the cause of MC. The possible underlying mechanism was suggested to be related to induction of apoptosis of epithelial cells in the colonic crypts. ${ }^{83}$ Other drugs that have been associated with the induction of $\mathrm{MC}$ include ranitidine, ${ }^{79}$ acarbose,${ }^{84}$ the venotonic drug Cyclo 3 forte, flutamide, ${ }^{30} \beta$-blockers, ${ }^{19}$ and statins. ${ }^{85}$ The association of statins with colitis has been based on an ischemic pathophysiology. ${ }^{86}$

\section{CONCLUSIONS}

Diarrhea is a frequent adverse event induced by drugs, accounting for about $7 \%$ of all adverse effects of drug therapy and over 700 drugs have been claimed to cause diarrhea. ${ }^{87}$ Drugs or their metabolites may cause diarrhea directly through their pharmacological properties or through idiosyncratic hypersensitivity reactions. Furthermore, drugs can alter the colonic microbiota and subsequently cause diarrhea.

The concept that some drugs may cause or worsen MC was first proposed in the $1990 \mathrm{~s} .{ }^{20,23}$ Olesen et al ${ }^{88}$ estimated $10 \%$ of all MC cases to be induced by drugs. The low frequency of $\mathrm{MC}$ associated with drugs of different pharmacodynamic profile, on the other hand, favors the pathophysiological mechanism to be of idiosyncratic nature. Resolution of symptoms after discontinuation of a drug and recurrence of diarrhea after rechallenge is a strong argument for such an idiosyncratic drug reaction. In a recent literature review, Beaugerie and Pardi ${ }^{50}$ suggested the use of a scoring system to determine the strength of evidence that associated individual drugs or drug classes with MC. NSAIDs, aspirin, PPIs, ranitidine, selective serotonin reuptake inhibitors, ticlopidine, acarbose, and statins had high or intermediate levels of association with the disease. Carbamazepine, flutamide, and paroxetine had less well-established associations with MC. A more recent study indeed confirmed a role for NSAIDs, selective serotonin reuptake inhibitors, statins, and PPIs, but also bisphosphonates and $\beta$-blockers. ${ }^{19}$ Reports have also proposed that aspirin, sertraline, simvastatin, and lanzoprazole may be more likely to be associated with MC than other medications in the corresponding classes. ${ }^{19,50}$

In principle, the causative role of a certain drug can be proven by demonstrating that (a) intake of the drug precedes the manifestation of disease, (b) discontinuation of a certain drug results in symptom resolution (dechallenge), (c) recurrence of the disease when medication is resumed (rechallenge), and (d) other causes of disease have been excluded. However, for most drugs having been associated with MC, rechallenge has not been performed or reported and the number of cases is small, such that an association by chance cannot be ruled out. Apart from case reports, the very limited number of retrospective studies assessing medication use and presence of disease generally do not allow to establish a cause-effect relationship as such studies are largely confounded by other factors, such as comorbid conditions, for which the use of certain pharmacological therapy is indicated. Furthermore, depending on the methods used for data acquisition, recall bias can largely influence drug exposure rates. Performing such studies aimed at defining certain associations in $\mathrm{MC}$ is challenging considering the higher age of patients affected and thereby frequent medication use. Such approaches should, however, be able to shed light on a positive association between the use of certain drugs and the disease condition. This enables the formulation of working hypotheses, provided that biological plausibility to ascertain a legitimate causative role of a drug is present.

Several factors can be found to explain a positive association with drug exposure and MC, apart from a cause-andeffect relationship. First, as for NSAIDs, many drugs that are associated with MC, including PPIs, induce watery diarrhea as common adverse effect. Thus, by causing or worsening diarrhea, use of these drugs can result in identification of MC, rather than being the primary etiological factor. 


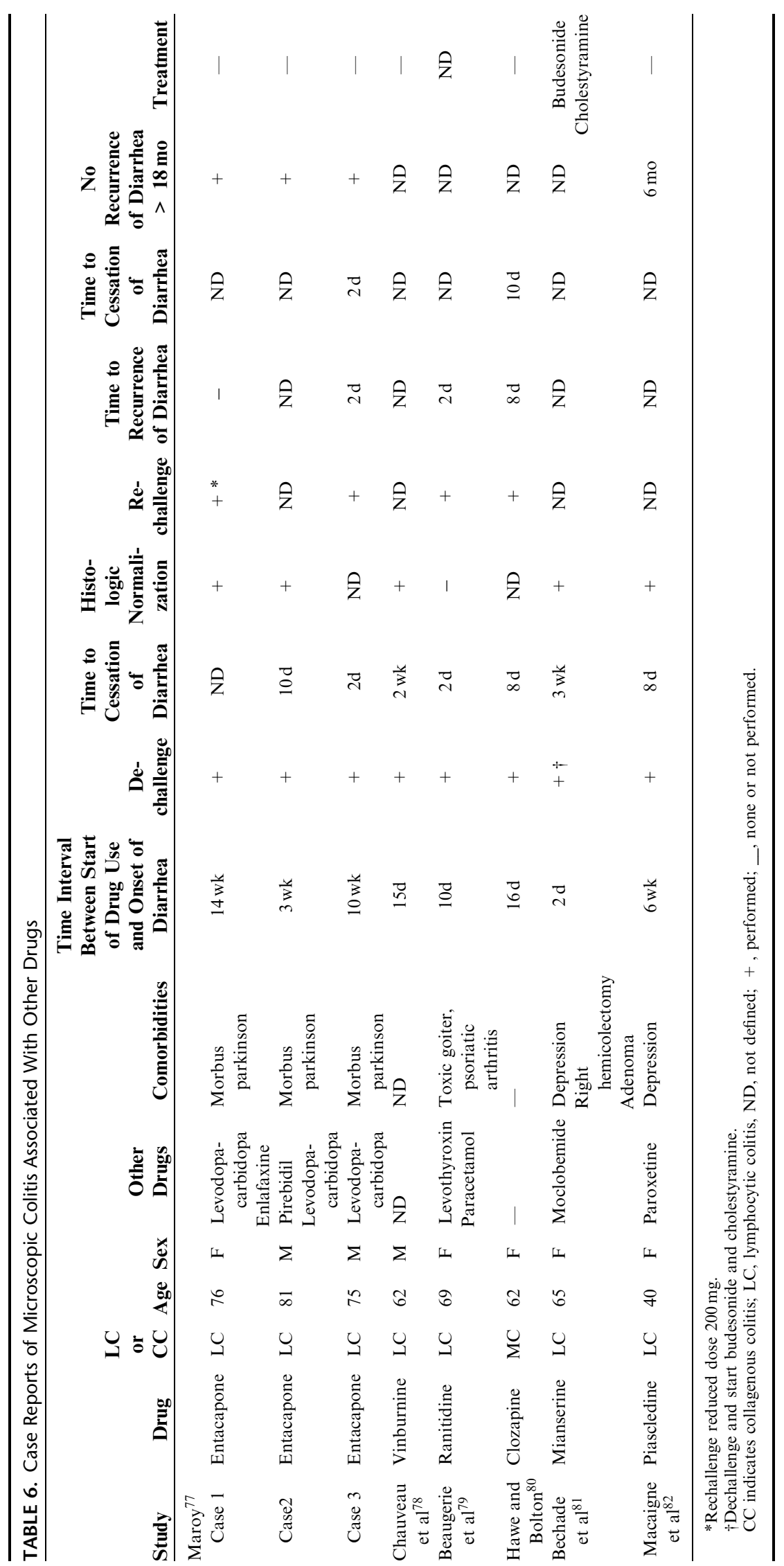


Second, one should consider that greater awareness of physicians and subsequent increase in exposure to colonoscopy with biopsy among patients receiving these medications may merely lead to an apparent increase in the diagnosis of MC.

Third, the growing list of distinct drugs and drug classes potentially associated with $\mathrm{MC}$, and largely variable time interval between start of drug use and onset of MC symptoms, indicate the great difficulty in establishing an association between specific agents and MC. ${ }^{35}$ Nevertheless, because of the associations between MC and NSAIDs, PPIs, and other medications, in individual cases, drug use and recent history should be carefully reviewed in patients with watery diarrhea or newly diagnosed MC. Agents that cause symptoms might be identified based on the temporal relationship between the timing of drug use and onset of symptoms.

The fact that most case reports of drug-induced MC concern suspected adverse drug reactions remains an inherent problem in pharmacovigilance. Adverse reactions are rarely specific for the drug and a rechallenge, which can add suggestive evidence for a causative role, is rarely ethically justified. In an attempt to solve this problem, many systems have been developed for a structured and harmonized assessment of causality, the most commonly used being the WHO-Uppsala Monitoring Center ${ }^{89}$ and the Naranjo criteria. ${ }^{90}$ None of these systems, however, have been shown to produce a precise and reliable quantitative estimation of relationship likelihood resulting in a lack of international consensus regarding causality assessment.

Nevertheless, valid arguments for causality have been provided by studies showing marked improvement in symptoms or histology after stopping the drug and in some cases rechallenge resulting in symptom relapse. Overall, evidence exists to support the role of certain drugs, in particular NSAIDs and PPIs, are able to contribute to the development of MC. In terms of disease development, it is tempting to assume that MC induced by a heterogeneous group of drugs possibly shares a common multistep pathophysiology related to the impairment of the intestinal epithelial barrier. Drug-induced impairment of the barrier may set the stage for further, as yet undetermined, insults through a luminal antigen that precipitates the disease. By virtue of interfering with intestinal homeostasis, they may potentially initiate or exacerbate ongoing unfavorable mucosal immune activation resulting in clinically manifest MC. Even though accumulating evidence suggests a role for certain drugs in disease development, it is obviously not the sole factor in MC.

In conclusion, we systematically reviewed the literature on medication use and MC. In individual cases, drugs such as NSAIDs and PPIs should be considered as potential etiological factors. Patients taking these drugs may therefore warrant investigation for $\mathrm{MC}$ when developing watery diarrhea. It is crucial to ascertain the temporal relationship between exposure and symptom onset to support a causative role. After diagnosis, attempt should be made to discontinue the suspected drug. Although a number of hypotheses have been formulated with regard to potential pathophysiological mechanisms in drug-induced $\mathrm{MC}$, confirmative evidence is still largely lacking. Given the wide use of these drugs among the general population and the relative rarity of the condition, drug-induced MC seems to be an uncommon complication, which most probably simply reflects an unfortunate idiosyncratic reaction to the particular drug.

\section{REFERENCES}

1. Pardi DS. Microscopic colitis: an update. Inflamm Bowel Dis. 2004;10:860-870.

2. Pardi DS, Smyrk TC, Tremaine WJ, et al. Microscopic colitis: a review. Am J Gastroenterol. 2002;97:794-802.

3. Pardi DS, Kelly CP. Microscopic colitis. Gastroenterology. 2011;140:1155-1165.

4. Pardi DS, Loftus EV Jr, Smyrk TC, et al. The epidemiology of microscopic colitis: a population based study in Olmsted County, Minnesota. Gut. 2007;56:504-508.

5. Bohr J, Tysk C, Eriksson S, et al. Collagenous colitis in Orebro, Sweden, an epidemiological study 1984-1993. Gut. 1995;37:394-397.

6. Olesen M, Eriksson S, Bohr J, et al. Microscopic colitis: a common diarrhoeal disease. An epidemiological study in Orebro, Sweden 1993-1998. Gut. 2004;53:346-350.

7. Agnarsdottir M, Gunnlaugsson O, Orvar KB, et al. Collagenous and lymphocytic colitis in Iceland. Dig Dis Sci. 2002;47:1122-1128.

8. Fernandez-Banares F, Salas A, Forne M, et al. Incidence of collagenous and lymphocytic colitis: a 5-year populationbased study. Am J Gastroenterol. 1999;94:418-423.

9. Williams JJ, Kaplan GG, Makhija S, et al. Microscopic colitisdefining incidence rates and risk factors: a populationbased study. Clin Gastroenterol Hepatol. 2008;6:35-40.

10. Jarnerot G, Hertervig E, Granno C, et al. Familial occurrence of microscopic colitis: a report on five families. Scand $J$ Gastroenterol. 2001;36:959-962.

11. Abdo AA, Zetler PJ, Halparin LS. Familial microscopic colitis. Can J Gastroenterol. 2001;15:341-343.

12. LaSala PR, Chodosh AB, Vecchio JA, et al. Seasonal pattern of onset in lymphocytic colitis. $J$ Clin Gastroenterol. 2005;39:891-893.

13. Kao KT, Pedraza BA, McClune AC, et al. Microscopic colitis: a large retrospective analysis from a health maintenance organization experience. World J Gastroenterol. 2009;15:3122-3127.

14. Hwang WS, Kelly JK, Shaffer EA, et al. Collagenous colitis: a disease of pericryptal fibroblast sheath? J Pathol. 1986;149: 33-40.

15. Widgren S, Jlidi R, Cox JN. Collagenous colitis: histologic, morphometric, immunohistochemical and ultrastructural studies. Report of 21 cases. Virchows Arch A Pathol Anat Histopathol. 1988;413:287-296.

16. Wang KK, Perrault J, Carpenter HA, et al. Collagenous colitis: a clinicopathologic correlation. Mayo Clin Proc. 1987;62:665-671.

17. Tangri V, Chande N. Microscopic colitis: an update. J Clin Gastroenterol. 2009;43:293-296.

18. Keszthelyi D, Jansen SV, Schouten GA, et al. Proton pump inhibitor use is associated with an increased risk for microscopic colitis: a case-control study. Aliment Pharmacol Ther. 2010;32:1124-1128.

19. Fernandez-Banares F, Esteve M, Espinos JC, et al. Drug consumption and the risk of microscopic colitis. Am J Gastroenterol. 2007;102:324-330.

20. Riddell RH, Tanaka M, Mazzoleni G. Non-steroidal antiinflammatory drugs as a possible cause of collagenous colitis: a case-control study. Gut. 1992;33:683-686.

21. Huedo-Medina TB, Sanchez-Meca J, Marin-Martinez F, et al. Assessing heterogeneity in meta-analysis: Q statistic or I2 index? Psychol Methods. 2006;11:193-206.

22. Milman N, Kraag G. NSAID-induced collagenous colitis $J$ Rheumatol. 2010;37:2432-2433.

23. Giardiello FM, Hansen FC 3rd, Lazenby AJ, et al. Collagenous colitis in setting of nonsteroidal antiinflammatory drugs and antibiotics. Dig Dis Sci. 1990;35:257-260.

24. Yagi K, Nakamura A, Sekine A, et al. Nonsteroidal antiinflammatory drug-associated colitis with a histology of collagenous colitis. Endoscopy. 2001;33:629-632.

25. Al-Ghamdi MY, Malatjalian DA, Veldhuyzen van Zanten S. Causation: recurrent collagenous colitis following repeated use of NSAIDs. Can J Gastroenterol. 2002;16:861-862. 
26. Dharancy S, Dapvril V, Dupont-Evrard F, et al. Cyclo 3 Fortinduced lymphocytic colitis associated with ileal villous atrophy. Gastroenterol Clin Biol. 2000;24:134-135.

27. Beaugerie L, Luboinski J, Brousse N, et al. Drug induced lymphocytic colitis. Gut. 1994;35:426-428.

28. Macaigne G, Al Jannoud A, Boivin JF, et al. Esberiven Fortassociated lymphocytic colitis. Gastroenterol Clin Biol. 2008;32: 697-698.

29. Tanner AR, Raghunath AS. Colonic inflammation and nonsteroidal anti-inflammatory drug administration. An assessment of the frequency of the problem. Digestion. 1988;41: $116-120$.

30. Baert F, Wouters K, D'Haens G, et al. Lymphocytic colitis: a distinct clinical entity? A clinicopathological confrontation of lymphocytic and collagenous colitis. Gut. 1999;45: 375-381.

31. Goff JS, Barnett JL, Pelke T, et al. Collagenous colitis: histopathology and clinical course. Am J Gastroenterol. 1997; 92:57-60.

32. Bjarnason I, Hayllar J, MacPherson AJ, et al. Side effects of nonsteroidal anti-inflammatory drugs on the small and large intestine in humans. Gastroenterology. 1993;104:1832-1847.

33. Sveinsson OA, Orvar KB, Birgisson S, et al. Clinical features of microscopic colitis in a nation-wide follow-up study in Iceland. Scand J Gastroenterol. 2008;43:955-960.

34. Pardi DS, Ramnath VR, Loftus EV Jr, et al. Lymphocytic colitis: clinical features, treatment, and outcomes. Am $J$ Gastroenterol. 2002;97:2829-2833.

35. Bohr J, Tysk C, Eriksson S, et al. Collagenous colitis: a retrospective study of clinical presentation and treatment in 163 patients. Gut. 1996;39:846-851.

36. Chande N, Driman DK, Reynolds RP. Collagenous colitis and lymphocytic colitis: patient characteristics and clinical presentation. Scand J Gastroenterol. 2005;40:343-347.

37. Jessurun J, Yardley JH, Giardiello FM, et al. Chronic colitis with thickening of the subepithelial collagen layer (collagenous colitis): histopathologic findings in 15 patients. Hum Pathol. 1987;18:839-848.

38. Etienney I, Beaugerie L, Viboud C, et al. Non-steroidal antiinflammatory drugs as a risk factor for acute diarrhoea: a case crossover study. Gut. 2003;52:260-263.

39. Gleeson MH, Davis AJ. Non-steroidal anti-inflammatory drugs, aspirin and newly diagnosed colitis: a case-control study. Aliment Pharmacol Ther. 2003;17:817-825.

40. Fortun PJ, Hawkey CJ. Nonsteroidal antiinflammatory drugs and the small intestine. Curr Opin Gastroenterol. 2005;21: 169-175.

41. Mahmud T, Scott DL, Bjarnason I. A unifying hypothesis for the mechanism of NSAID related gastrointestinal toxicity. Ann Rheum Dis. 1996;55:211-213.

42. Chande N, Driman DK. Microscopic colitis associated with lansoprazole: report of two cases and a review of the literature. Scand J Gastroenterol. 2007;42:530-533.

43. Hilmer SN, Heap TR, Eckstein RP, et al. Microscopic colitis associated with exposure to lansoprazole. Med J Aust. 2006;184:185-186.

44. Thomson RD, Lestina LS, Bensen SP, et al. Lansoprazoleassociated microscopic colitis: a case series. Am J Gastroenterol. 2002;97:2908-2913.

45. Wilcox GM, Mattia AR. Microscopic colitis associated with omeprazole and esomeprazole exposure. J Clin Gastroenterol. 2009;43:551-553.

46. Ghilain JM, Schapira M, Maisin JM, et al. Lymphocytic colitis associated with lansoprazole treatment. Gastroenterol Clin Biol. 2000;24:960-962.

47. Mukherjee S. Diarrhea associated with lansoprazole. J Gastroenterol Hepatol. 2003;18:602-603.

48. Wilcox GM, Mattia A. Collagenous colitis associated with lansoprazole. J Clin Gastroenterol. 2002;34:164-166.

49. Rammer M, Kirchgatterer A, Hobling W, et al. Lansoprazoleassociated collagenous colitis: a case report. Z Gastroenterol. 2005;43:657-660.
50. Beaugerie L, Pardi DS. Review article: drug-induced microscopic colitis - proposal for a scoring system and review of the literature. Aliment Pharmacol Ther. 2005;22:277-284.

51. Capurso G, Marignani M, Attilia F, et al. Lansoprazoleinduced microscopic colitis: an increasing problem? Results of a prospective case-series and systematic review of the literature. Dig Liver Dis. 2011;43:380-385.

52. Forgacs I, Loganayagam A. Overprescribing proton pump inhibitors. BMJ. 2008;336:2-3.

53. Mullin JM, Gabello M, Murray LJ, et al. Proton pump inhibitors: actions and reactions. Drug Discov Today. 2009; 14:647-660.

54. Nakamura M, Matsui H, Serizawa H, et al. Lansoprazole novel effector sites revealed by autoradiography: relation to Helicobacter pylori, colon, esophagus and others. J Clin Biochem Nutr. 2007;41:154-159.

55. Murray LJ, Gabello M, Rudolph DS, et al. Transmucosal gastric leak induced by proton pump inhibitors. Dig Dis Sci. 2009;54:1408-1417.

56. Mullin JM, Valenzano MC, Whitby M, et al. Esomeprazole induces upper gastrointestinal tract transmucosal permeability increase. Aliment Pharmacol Ther. 2008;28:1317-1325.

57. Burgel N, Bojarski C, Mankertz J, et al. Mechanisms of diarrhea in collagenous colitis. Gastroenterology. 2002;123:433-443.

58. Tagkalidis PP, Gibson PR, Bhathal PS. Microscopic colitis demonstrates a $\mathrm{T}$ helper cell type 1 mucosal cytokine profile. J Clin Pathol. 2007;60:382-387.

59. Broeren MA, Geerdink EA, Vader HL, et al. Hypomagnesemia induced by several proton-pump inhibitors. Ann Intern Med. 2009;151:755-756.

60. Cundy T, Dissanayake A. Severe hypomagnesaemia in longterm users of proton-pump inhibitors. Clin Endocrinol (Oxf). 2008;69:338-341.

61. Gouraud A, Vochelle V, Descotes J, et al. Proton pump inhibitor-induced neutropenia: possible cross-reactivity between omeprazole and pantoprazole. Clin Drug Investig. 2010;30:559-563.

62. Dury S, Nardi J, Gozalo C, et al. Agranulocytosis induced by proton pump inhibitors. J Clin Gastroenterol. 2012. [Epub ahead of print].

63. Lewis SJ, Franco S, Young G, et al. Altered bowel function and duodenal bacterial overgrowth in patients treated with omeprazole. Aliment Pharmacol Ther. 1996;557-561.

64. Williams C, McColl KE. Review article: proton pump inhibitors and bacterial overgrowth. Aliment Pharmacol Ther. 2006;23:3-10.

65. Thorens J, Froehlich F, Schwizer W, et al. Bacterial overgrowth during treatment with omeprazole compared with cimetidine: a prospective randomised double blind study. Gut. 1996;39:54-59.

66. Fried M, Siegrist H, Frei R, et al. Duodenal bacterial overgrowth during treatment in outpatients with omeprazole. Gut. 1994:35:23-26.

67. Vesper BJ, Jawdi A, Altman KW, et al. The effect of proton pump inhibitors on the human microbiota. Curr Drug Metab. 2009; 10:84-89.

68. Spiegel BM, Chey WD, Chang L. Bacterial overgrowth and irritable bowel syndrome: unifying hypothesis or a spurious consequence of proton pump inhibitors? Am J Gastroenterol. 2008;103:2972-2976.

69. Drug Safety FDA. Communication: Clostridium difficile-associated diarrhea can be associated with stomach acid drugs known as proton pump inhibitors (PPIs). February 8, 2012. Available at: http://www.fda.gov/Drugs/DrugSafety/ucm290510.htm. Accessed May 12, 2012.

70. Lombardo L, Foti M, Ruggia O, et al. Increased incidence of small intestinal bacterial overgrowth during proton pump inhibitor therapy. Clin Gastroenterol Hepatol. 2010;8:504-508.

71. Spiegel BM. Questioning the bacterial overgrowth hypothesis of irritable bowel syndrome: an epidemiologic and evolutionary perspective. Clin Gastroenterol Hepatol. 2011;9: 461-469; quiz e59. 
72. Gustafsson RJ, Ohlsson B, Benoni C, et al. Mucosa-associated bacteria in two middle-aged women diagnosed with collagenous colitis. World J Gastroenterol. 2012;18:1628-1634.

73. Wildt S, Munck LK, Vinter-Jensen L, et al. Probiotic treatment of collagenous colitis: a randomized, double-blind, placebo-controlled trial with Lactobacillus acidophilus and Bifidobacterium animalis subsp. Lactis. Inflamm Bowel Dis. 2006;12:395-401.

74. Maiden L, Thjodleifsson B, Theodors A, et al. A quantitative analysis of NSAID-induced small bowel pathology by capsule enteroscopy. Gastroenterology. 2005;128:1172-1178.

75. Fujimori S, Gudis K, Takahashi Y, et al. Distribution of small intestinal mucosal injuries as a result of NSAID administration. Eur J Clin Invest. 2010;40:504-510.

76. Wallace JL, Syer S, Denou E, et al. Proton pump inhibitors exacerbate NSAID-induced small intestinal injury by inducing dysbiosis. Gastroenterology. 2011;141:1314-1322. [22 e1-5].

77. Maroy B. Entocapone-related lymphocytic colitis. Gastroenterol Clin Biol. 2008;32:695-697.

78. Chauveau E, Prignet JM, Carloz E, et al. Lymphocytic colitis likely attributable to use of vinburnine (Cervoxan). Gastroenterol Clin Biol. 1998;22:362.

79. Beaugerie L, Patey N, Brousse N. Ranitidine diarrhoea, and lymphocytic colitis. Gut. 1995;37:708-711.

80. Hawe R, Bolton JM. Response to clozapine-induced microscopic colitis: a case report and review of the literature. J Clin Psychopharmacol. 2008;28:454-455.
81. Bechade D, Desrame J, Raynaud JJ, et al. Lymphocytic colitis following administration of mianserine. Rev Med Interne. 2006;27:78-80.

82. Macaigne G, Ozon N, Dikov D, et al. Piascledine-associated lymphocytic colitis. Gastroenterol Clin Biol. 2004;28:412-413.

83. Berrebi D, Sautet A, Flejou JF, et al. Ticlopidine induced colitis: a histopathological study including apoptosis. J Clin Pathol. 1998;51:280-283.

84. Piche T, Raimondi V, Schneider S, et al. Acarbose and lymphocytic colitis. Lancet. 2000;356:1246.

85. Mukhopadhya A, Gilmour H, Plevris J. Pravastatin-induced colitis. Eur J Gastroenterol Hepatol. 2008;20:810-812.

86. Leung FW, Lieberman J, Fagen N, et al. Colonoscopic features of simvastatin-induced colitis suggest ischemia as an etiologic mechanism. Gastrointest Endosc. 2005;62:175-178.

87. Chassany O, Michaux A, Bergmann JF. Drug-induced diarrhoea. Drug Saf. 2000;22:53-72.

88. Olesen M, Eriksson S, Bohr J, et al. Lymphocytic colitis: a retrospective clinical study of 199 Swedish patients. Gut. 2004;53:536-541.

89. The use of the WHO-UMC system for standardised case causality assessment. Available at: http://who-umc.org/ Graphics/24734.pdf. Accessed May 12, 2012.

90. Naranjo CA, Busto U, Sellers EM, et al. A method for estimating the probability of adverse drug reactions. Clin Pharmacol Ther. 1981;30:239-245. 